\title{
EVALUATION OF THE EFFECTIVENESS IN THE RECOVERY OF WATER CONTAMINATED BY HYDROCARBONS, THROUGH THE TECHNIQUE OF PHYTOREMEDIATION USING VETIVER GRASS
}

\author{
CLAUDIA L HERNÁNDEZ G ${ }^{1}$, CARLOS A RODRÍGUEZ P ${ }^{1}$, \\ CARLOS A AMAYA $\mathbf{C}^{1} \&$ MIGUEL ÁVILA. ${ }^{2}$ \\ ${ }^{1}$ Engineering Environment, Unidades Tecnológicas de Santander, Bucaramanga, Colombia \\ ${ }^{2}$ Engineering Faculty, Universidad Distrital Francisco José de Caldas, Bogotá, Colombia
}

\begin{abstract}
The present work was based on the study and evaluation of an alternative treatment, for the reduction of the pollutant load of the production residual waters, generated in the oil field of Chichemene, in the department of Meta, located in the region of the eastern plains of Colombia. The methodology used was based on phases, where in the first phase a diagnosis of the hydrocarbon production process in an oil field was made, in the second phase the state of the art of the phytoremediation process of the production waters was investigated, using the vetiver grass technique, in the third and last phase, some treatment alternatives were selected that, together with the pilot cultivation of vetiver, reduce the contaminating load of the production waters in an oil field. The activities carried out in the development of this work allowed to synthesize the following results: identification of the chemical components that the production water has; the treatment system of the water produced by the vetiver grass technique, in order to reduce the pollutant loads in the production water in the Chichemene Field.
\end{abstract}

KEYWORDS: Contamination, Foliage, Phytoremediation, Petroleum, Removal, Vetiver

Received: Oct 28, 2020; Accepted: Nov 18, 2020; Published: Dec 4, 2020; Paper Id.: IJMPERDDEC20207

\section{INTRODUCTION}

One of the most alarming environmental problems at present is the contamination of aquatic ecosystems, caused by anthropogenic activities such as the exploitation of hydrocarbons. This process includes the generation of liquid and solid waste from the extraction phases to the refining.In Colombia there are crude oil spills, due to accidents in the activities that comprise the extraction process, added to the security problems that the country is experiencing with the groups outside the law, which during the last thirty years have caused the spilling of nearly two million barrels of oil, all of this causing a negative alteration in the different natural resources,present in the ecosystems surrounding the oil spill site. [1]

In order to extract crude oil it is necessary to apply the stages that the technique has, first, the deposit is located, then the land is drilled by digging a well, and thus to arrive at the oil. A 50 meter high metal tower must be installed to advance in the extraction of the oil. If there is no problem, it is normal that the pipeline that connects through the well allows the obtaining of the material for treatment.

Once the extraction has been achieved, there is the process of eliminating unnecessary compounds, which hinder the formation of the oil, so it is necessary to use certain techniques for this, such as extraction by water injection pumps. In the process of extracting crude oil, waste is generated that contaminates the various natural 
resources, but this study focuses on the impact generated on water resources, especially in the production waters which are contaminated with compounds that form oil.

For this problem it is proposed to guide this research to the design of a treatment alternative with vetiver system, which allows to know the effectiveness in the application of the technique of biostimulated phytoremediation for the recovery of hydrocarbon-contaminated waters.

\section{MATERIALS AND METHODS}

During 2006, a study of the feasibility of aquatic plants for the treatment of domestic and industrial waste water was carried out, through the exposure of the different biological processes that are carried out, likewise concluding the high feasibility and applicability that these hydroponic species have for the capture and removal of contaminants in this type of waste water. [2]

In the year 2013, the treatment of waste water by means of filters and natural hydrosystems with vetiver grass will be exposed. This paper contains important information about the implementation and construction of artificial wetlands withvetiver grass, taking into account different aspects and parameters necessary in this whole process, such as the adequacy of the land, vetiver grass sowing, care, advantages and important functions of this phytoremediation process for contaminated water, it is important to name the progress that was generated in terms of identifying the percentages of pollutant removal in load for this treatment. [3]

In the year 2016, alternatives are shown for the design of the Campo Escuela Colorado production water treatment system, in accordance with current regulations for discharge in Colombia. It shows the environmental impacts generated by the production water when it is discharged into a water body or into the sewerage system without a respective treatment to remove the load, it also describes the evolution of the regulations with reference to this issue, on the other hand, it identifies the decontamination treatments of produced water, most used in oil fields as a basis for the formulation of programs to reduce the alteration that is being generated on the water resource and the surrounding environment. [4]

This study is carried out with the support of the Universidad Agrícola de Venezuela in 2017, about the different forms for the establishment of vetiver grass sowing in nursery modality, at the same time it enunciates the care and the aspects to take into account to carry out the cultivation successfully, it also makes reference to the need of implementing these biological treatments in the recovery of contaminated water in industrial processes, based on the effectiveness of the same and its easy adaptation to the different life zones of the planet. [5]

Oil is the fossil source of energy for massive use; it is a resource in numerous industrial processes. Oil and coal originate from sedimentary rocks, oil comes from the decomposition of organic matter (especially animal remains or large plankton masses in a marine environment). It is a resource used as primary energy, since the oil crisis in 1973, motivated by the alarming rise in oil prices decreed by OPEC (Organization of Petroleum Exporting Countries), has stabilized consumption, even getting several countries to diversify their energy dependence. Petroleum is a dark-colored liquid, oily in appearance, with a strong odor and a density between 0.8 and 0.95 . mixture of hydrocarbons. [6].

The formation of the oil is decanted by rocks, from mother rock, it moves to a porous rock or reservoir, where it is trapped in an impermeable layer, in a geological trap and these are determined by the characteristic of the earth that can have diverse forms. 


\section{DEVELOPMENT AND RESULTS}

\subsection{Types of Pollutants Present in Wastewater from the Oil Field in the Hydrocarbon Production Process.}

Produced water is the water that comes out associated with the oil or gas when it is extracted from the reservoir to the surface, either from a formation of interest (connata water), an active aquifer (intrusive water) or from a reinjection project (injected water). So these waters vary from well to well and tend to increase over time. And it is common to find contaminants such as: suspended and dissolved solids, residual crude and others, which are particular to each formation.Therefore, it can be said that in the reservoirs there are rocks that are naturally impregnated with different fluids such as water, oil and gas. Similarly, when the extraction of hydrocarbons is done, these fluids tend to be collected at the surface and bring with them a certain amount of water which is usually called "production water". [7]

A physicochemical analysis is required to determine the specific components of each water. In addition, it is advisable to know and identify each constituent present in the water associated with the production of hydrocarbons, in order to establish the origin of the most frequent problems in a system. These components of the production water come from their contact with theformation minerals, hydrocarbon compounds and solids. Cations refer to those solid contaminants that are dissolved whose charges are positive, and have a tendency to form organic scale incrustations. Calcium (Ca2+), Sodium (Na+), Barium (Ba2+), Magnesium (Mg2+), Iron (Fe2+, Fe3+), Strontium ( $\mathrm{Sr} 2+)$, Cadmium $(\mathrm{Cd} 2+)$. Anions are substances belonging to the formation, which have negative charges and are responsible for generating incrustations along with the cations: Carbonate and Bicarbonate (CO32-, $\mathrm{HCO} 3-)$, Sulfate (SO42-), Chloride (Cl-). [8]Among other components it is found:pH, the Biochemical Oxygen Demand (BOD), Chemical Oxygen Demand (COD), Phenols, Ammonia, Total dissolved solids.

\subsection{Vetiver Grass}

Vetiver grass is a perennial grass with a massive, deep root system (2 to $3 \mathrm{~m}$ of growth in a year); strong, its tensile strength is $75 \mathrm{MPa}$, equivalent to $1 / 6$ of soft steel, which makes it an enclave of the soil. It has straight, leafy and strong foliage; it supports sheets of water of considerable proportion, about $80 \mathrm{~cm}$ and almost zero obstruction of water transit, while retaining sediments. It is an asexual plant, that is, its seeds are not fertile, and therefore there is no risk of it becoming a weed. Once established, it tolerates extreme conditions of drought, flooding and burning. [9]

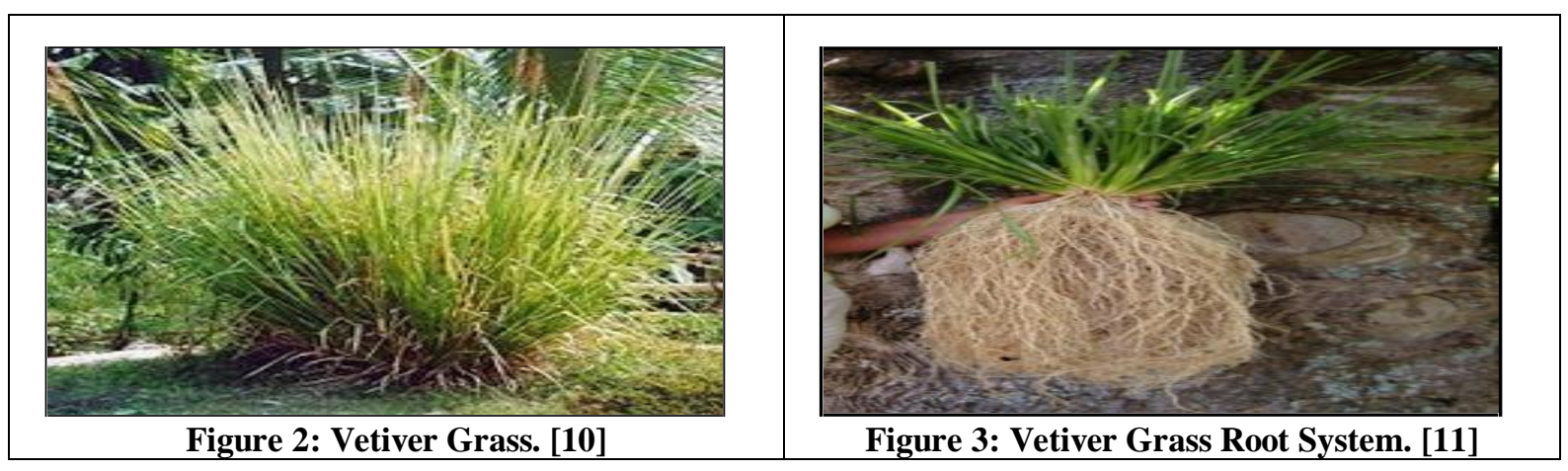

Vetiver grass reproduces faster in warm climates, while it works well in cold climates, having wide limits of growing temperature. Between $-9^{\circ} \mathrm{C}$ to over $45^{\circ} \mathrm{C}$. The plant supports extreme droughts, but normally requires a rainy season that lasts at least 3 months. Vetiver grass grows in deep lean sandy soils. It can grow in rocky and wide areas with extreme acid 
and base $\mathrm{PH}$, it supports toxic levels of metals such as aluminum, manganese (550 ppm) and sodium and salt conditions. It has a high level of support to floods without requiring deep soils.

Its massive root system generally grows vertically and does not compete with adjacent crops. Its root system can grow to a depth of $5 \mathrm{~m}$ and form a root barrier that stabilizes soils by tying it to slopes, gables, and roadsides. The roots will penetrate to layer " $\mathrm{C}$ " and inside the rotten rock (saprolite), and grow in cracks in the rotten rock, as shown in Figure 3.

Vetiver grass reproduces faster in warm climates, while it works well in cold climates, having wide limits of growing temperature. Between $-9^{\circ} \mathrm{C}$ to over $45^{\circ} \mathrm{C}$. The plant supports The plant works without major technological support for water treatment, which makes it recognized in the field of bioengineering to decontaminate water from oil spills. The investment in the Vetiver system for the treatment of contaminated water costs a fraction in relation to the use of chemical and mechanical methods, besides, it is an organic and sustainable system, with easy material reproduction. The process is limited to the depth of root penetration or shallow water. However, taking into account that the vetiver grass species has a root system that can reach 3 to $5 \mathrm{~m}$ in length. The process times can be very long and the bioavailability of the compounds or metals is a limiting factor of the uptake. [7]

\subsection{Contamination Control Processes using Bioremediation Processes}

In Colombia, the basic chemical, petrochemical and oil refining industries have produced large quantities of hazardous waste that are difficult to quantify. According to figures published by INGEOMINAS, the oil industry may have affected areas close to 55,967 km2 of degraded soil.Mining activity in the Pacific Region and Orinoco region of Colombia is significant in all variables of the country's development. Environmental audits have identified natural soil contaminated with hydrocarbons, about 800 tons in the Orinoco region. In addition, complementary activities to oil extraction, such as maintenance of machinery and equipment, have been carried out. These difficulties have had good answers with alternative methods to the traditional chemical or petrochemical ones and supported in the bioremediation it has been possible to control those levels of natural soil affectation. [8]

There are numerous technologies for remediation of contaminated soils [9] that can be grouped into 3 types: a) biological (bioremediation, biostimulation, phytoremediation, biolabrancy, etc.), where the metabolic activities of certain organisms allow the degradation, transformation or removal of contaminants to harmless metabolic products [10]

Bioremediation seeks to manage endogenous species, although it is not limited to the presence of exogenous species of affected soils, it allows working in in situ or ex situ conditions, in aerobic (in presence of oxygen) or anaerobic (without oxygen) conditions. Bioremediation processes have been successfully used to treat soils, sludges and sediments contaminated with petroleum hydrocarbons, and multiple affectations of soils that due to their dimension or extension require mechanisms that manage to cover the affected surfaces, plants such as grasses achieve these coverings and soil recovery. [11]

The microorganisms in the soils are the primary agents of contaminant degradation, therefore the higher the microbial density in a contaminated soil, the faster the degradation of organic contaminants is expected, logically considering the hydrocarbons[12]. Therefore, in bioremediation the variable to be controlled is the existence of native soil microorganisms, for which the load of nutrients in the soil is important, naturally or assisted. This is justified, understanding that the entry of hydrocarbons into the soil alters the natural balance of nutrients in the system, affecting 
elements such as nitrogen and phosphorus, and thus reducing or stopping the rate of bacterial growth. [13]

The high concentrations of inorganic nitrogen, phosphorus and organic matter in sewage sludge contain, are a fundamental characteristic to stimulate the microbial activity of the soil. This condition makes them an important source of macro and micronutrients that must promote good performance in the degradation of hydrocarbons[14].

Bioremediation is a mineralization process, also known as composting. With this process, the residual sludge is controlled and humus is obtained as a derivative, which is recognized in all areas as a high quality nutrient to recover the soil. Therefore, adding sludge to hydrocarbon-contaminated soils, allows to restore a soil improved in its physical characteristics and without the contaminant, suitable to be used in any agricultural activity. [15].

\subsection{Types of Contaminant Loads that are Removed with the Vetiver System}

Vetiver Grass. Due to its root characteristics, it is very efficient in the removal of contaminants in water, controlling macronutrients such as Nitrogen, Phosphorus or heavy metals: Nickel, Cadmium, Lead, Mercury, Cyanide and Fluorine, it is also identified as having good performance in the retention of some cations.

Vetiver Grass efficiency data on retention of contaminants shows figures like being able to lower total nitrogen from 100 mgL-1 to 6 mgL-1 (94 \% efficiency); total phosphorus from $10 \mathrm{mgL}-1$ to $1 \mathrm{mgL}-1$ (90 \%), Fecal Coliforms $\geq 1.600 \mathrm{org} / 100 \mathrm{~mL}$ to $900 \mathrm{org} / 100 \mathrm{~mL}$ (44 \%); E. Coli\%), E. Coli from $\geq 1.600 \mathrm{org} / 100 \mathrm{~mL}$ to $140 \mathrm{org} / 100 \mathrm{~mL}$ (91\%); dissolved oxygen from < $1 \mathrm{mgL}-1$ to $8 \mathrm{mgL}-1$ ( $>800$ ); electrical conductivity from $928 \mu \mathrm{Scm}-1$ to $468 \mu \mathrm{Scm}-1 ; \mathrm{pH} 7.3$ to 6.0 and can evaporate $1.1 \mathrm{~L} /$ day/four plants/drum, all with a retention time of four days. [16]Turbidity $90 \%$, COD 98\%, BOD 96\%, total suspended solids 70\%, sedimentablesolids 85\%, Fats and Oils 70-90\%, heavy metals 60_70\%, Phenols $80 \%$ and volatile organic compounds 50\% [17].

Vetiver grass is also recognized as having good degradation behavior, generating possible levels of material of up to 132 tons per hectare per year, which is highly superior to the average grass. In addition, important levels of identification of elements such as up to 1,920 kilograms of nitrogen and 198 kilograms of phosphorus per hectare per year; being able to reach supplies of up to 6,000 kilograms of nitrogen combined with a supply of 250 kilograms of phosphorus. The data on these two elements are important support for Vetiver's efficiency in wastewater treatment. To use this system, a mechanism of floating rafts must be implemented to which the necessary amount of vetiver plants are sown, so that they can absorb through their systems the greatest amount of compoundschemicals that carry the waste water, and that deliver to the natural water sources a highly decontaminated liquid, which in the process with vetiver grass exceeds $95 \%$, according to studies verified in Venezuela, India, China, Australia, Mexico and USA. [18]

\subsection{Feasibility of the Vetiver System in the Recovery of Contaminated Water in oil Extraction Operations.}

The feasibility or viability that was identified, once the search of bibliographical documentation was made, for the development and implementation of the system by means of artificial wetland with the incorporation of the vegetal species vetiver grass, in the recovery of polluted waters in operations of oil extraction, is summarized in the following aspects:

The areas where an oil field is established generally have large extensions of land, which is why the incorporation of an artificial system with vetiver grass is viable.The places where oil fields are established are generally located in high temperature zones, this factor not being uncomfortable for the germination and development of vetiver grass, since it supports a variety of climates. It is viable to implement it because it decreases the load of Total Nitrogen, Total 
Phosphorus, Fecal Coliforms, Electrical Conductivity, pH, increases the presence of Dissolved Oxygen.Vetiver Grass is a great purifier of water contaminated with the process of oil extraction, achieving decontamination of heavy substances such as Krypton, Argon, Calcium, Magnesium, Lead and Cadmium. [19]

It is both xerophytic and hydrophilic, once established it can resist drought, flooding and prolonged periods of waterlogging. Because vetiver roots have a high aromatic content they are used in the pharmaceutical industry for the extraction of essential oils and the manufacture of perfumes. [20]. Vetiver Grass biomass, its leaves and stems are currently used as combustion material for boilers in paper and cement industries, which reduce the level of air pollution. It is a perfectly adapted plant, so that even when all the other plants around have been destroyed by drought, floods, pests, diseases or other adverse circumstances, the vetiver remains in place to protect the soil from the next rains. [21]

\section{RESULTS}

Description of Alternatives Proposed for the Production Water Treatment System, Attached to the Vetiver Grass Pilot Crop

1) Storage lagoon. The lagoon consists of the storage of waste water for a variable time depending on the applied load and the climatic conditions. This structure is a natural biological method of treatment, based on the principle of self-purification. For the design of the lagoon, the average flow generated by an oil well located in the eastern plains of the country (Ecopetrol S.A.) was considered. The production water is obtained at the surface through oil wells, and the water will be sucked by a $220 \mathrm{~V}$ centrifugal pump, and will be transported through a $0.1016 \mathrm{~m}$ pipe.

The design of the lagoon depended on the surface load of the BOD, i.e. the amount of this parameter applied per unit of surface area of the lagoon per day. The area of the optional lagoon was calculated using equation (1):

$$
A=\frac{L i \mathrm{Q} \text { design }}{\operatorname{CS} \text { design }}
$$

Where: $\mathrm{A}=$ Area of the depth of the lagoon.

$\mathrm{Li}=\mathrm{BOD}$ of the tributary to the lagoon.

$\mathrm{Q}$ design $=$ Design flow rate of the lagoon .

Cs $=$ Design BOD surface load of the lagoon .

To find the surface load of BOD we had as a basis what was established by Matamoros for the design of lagoons, and we will take into account the following parameters, according to equation (2), the retention time for the storage pond was calculated with equation(3):

$$
\begin{aligned}
& \mathrm{CS}=357,4 * 1,085 T-20^{T-20} \\
& t=\frac{A h}{\text { Qdesign }}
\end{aligned}
$$

$\mathrm{h}=$ is the effective height of liquid in the pond, in theory the value of will be between 1.50 and $2.50 \mathrm{~m}$.

$\mathrm{t}=$ is the hydraulic retention time of the lagoon

After reviewing the calculations, the storage pond will have the following dimensions:Flow: $11.129 \mathrm{~m} 3 / \mathrm{d}$; Long: 121.4 m; Width: 27,6 m; Depth: 0.6 m; Surface Area: 3.350,5 m²; Retention time: 0,13 h; Piping: 0,1016 m; Affluent BOD: $125 \mathrm{~kg} / \mathrm{d}$.A $0.1016 \mathrm{~m}$ pipe runs through the middle of the lagoon, which has a large number of holes where the production water enters, this is conducted by the action of the centrifugal pump to the distribution tank. This storage pool is covered with a geomembrane to avoid production water filtration into the subsoil. 
2) Distribution tank. The supply of production water to the treatment process is carried out by thedistribution tank. The production water is transported by a $0.1016 \mathrm{~m}$ pipe to the distribution tank. A $5 \mathrm{~m} 3$ tank will be installed, according to the manufacturer's instructions, since it facilitates the wastewater treatment process and it is easier to regulate the flow rate to be treated. The pipelines were adapted,purge and overflow. The tank purge was installed from $0.0508 \mathrm{~m}$. The suction lines of the peripheral pumps were inserted at a depth of $0.5 \mathrm{~m}$ from the bottom ensuring that the suction of each pump does not suck in air or sludge, as shown in Figure 4. Each suction line has universal joints for cleaning in case of blockages.

3) Artificial wetland with vetiver grass. Once the production water is treated, it continues its journey through a $0.1016 \mathrm{~m}$ pipe, and enters the artificial wetland composed of Vetiver Grass. This technology is efficient in removal, easy to operate, does not require conventional energy, reduces the impact on aquatic environments by excess nutrients, reduces visual impacts and finally by its effectiveness and cleanliness in treatment. The species to establish the wetland have an average rooting of more than $0.60 \mathrm{~m}$. So the thickness of the bed in your case should be at least $0.6 \mathrm{~m}$. These species originating from India have fully adapted to Colombian territory and are suitable for industrial water treatment. A bed depth of $60 \mathrm{~cm}$ is chosen, recommended by the Technical Regulations of the Drinking Water and Basic Sanitation Sector in Colombia (RAS) for this type of wetlands. The bed slope is based on the topography of the site. Most Subsurface Flow wetland systems are designed with a slope of $1 \%$ or slightly higher. For this design, the recommendation of the SAN and other authors, with a $2 \%$ slope. Calculation of design temperature [22]. To know the design temperature is used equation (4)

$\mathrm{T}=$ design temperature, or $\mathrm{C}$.

Ta $=$ average air temperature during the coldest week of the

$$
T=T a+\frac{T o-T a}{3}
$$
year, or C.

To $=$ temperature of the tributary during the coldest week of the

$$
T=26^{\circ} \mathrm{C}+\frac{29^{\circ} \mathrm{C}-26^{\circ} \mathrm{C}}{3}=27^{\circ} \mathrm{C}
$$
year, or $\mathrm{C}$.

Calculate the first order kinetic constant. In subsurface flow wetlands it is common to use the equation for piston flow reactions. This equation you can determine the value of the constant $\mathrm{k}$.

$$
\mathrm{Kt}=\mathrm{k} \mu \mathrm{T}-20
$$

The temperature correction value ranges $\mu$ from 1.02 to 1.06 . It is common to work with 1.06.The value of for subsurface flow wetlands is $1,104 \mathrm{~d}-1$. It is clarified that these values vary according to the type of water and operating conditions. From experience in various designs of wetlands with subsurface flow, a k20 value of 1,104 d-1 has been established.

a) Surface area:

$$
\mathrm{Kt}=\text { temperature-dependent first-order } \quad A s=\frac{Q(\operatorname{lnCo}-\ln C i)}{K t(y)(n)}
$$

kinetic constant, d-1

$$
\mathrm{y}=\text { system depth, } \mathrm{m}
$$

$$
A s=\frac{11.129 \frac{\mathrm{m} 3}{\mathrm{~d}}(\ln 5-\ln 1)}{1,66^{d-1}(0,6 m)(0,36)}=49.954 m^{2}
$$


$\mathrm{n}$ = wetland porosity, decimal fraction.

b) $\quad$ Retention time $(\theta)$ :

$$
\varphi=\frac{V}{Q}=\frac{A s * y * n}{Q}=\frac{49.954 \mathrm{~m} 2 * 0,6 \mathrm{~m} * 0,36}{11.129 \mathrm{~m} 3 / \mathrm{d}}=0,96 \cong 1 d
$$

For piston flow considerations, length ratios of $2: 1,3: 1,4: 1$ or $5: 1$ can be taken. The dimensions with 5:1 ratios are then elaborated, 10 wetland cells will be built. The calculated area is then divided by 10 . This gives an area of approximately $4,995 \mathrm{~m} 2$ per wetland. It should be noted that the flow into each cell is approximately $11,129 \mathrm{~m} 3 / \mathrm{d}$.

$$
\mathrm{L}=5 \mathrm{~W} \quad \rightarrow \quad \mathrm{As}=\mathrm{LW} \rightarrow \mathrm{As}=5 \mathrm{WW}
$$

By defining the width to length ratios of the wetland as $1: 5$, the width $\mathrm{W}$ of the wetland obtained:

$$
w=\sqrt{\frac{A s}{5}}=\sqrt{\frac{4,99 m^{2}}{5}} 31,61 \mathrm{~m}
$$

Therefore: $\mathrm{L}=5 \mathrm{~W} \rightarrow \mathrm{L}=5(31,61 \mathrm{~m}) \rightarrow \quad \mathrm{L}=158,05 \mathrm{~m}$

The cross-sectional area is calculated with the following expression:

$A c=W * y=31,61 * 0,6 \mathrm{~m}==18,966 \mathrm{~m}^{2}=19 \mathrm{~m}^{2}$

With these measurements, each artificial wetland cell can be sized, as shown in Table I:

Table 1: Typical Media Characteristics for Artificial Wetlands

\begin{tabular}{|l|c|}
\hline \multicolumn{1}{|c|}{ Parameter } & Valor Por Celda De Humedal \\
\hline Depth (y) & $0,6 \mathrm{~m}$ \\
\hline Cross section (Ac) & $19 \mathrm{~m}^{2}$ \\
\hline Surface area (As) & $4996 \mathrm{~m}^{2}$ \\
\hline Length (L) & $158,05 \mathrm{~m}$ \\
\hline Width (W) & $31,61 \mathrm{~m}$ \\
\hline Flowrate (Q) & $11.129 \mathrm{~m} 3 / \mathrm{d}$ approximately \\
\hline Retention time $(\varphi)$ & $1 \mathrm{~d}$ \\
\hline Slope $(\mathrm{m})$ & $2 \%$ \\
\hline
\end{tabular}

\section{Source: Authors}

Below is the structure in plant and cut of the vetiver system, which is proposed as a phase in the production water treatment system in the Chichemene field.

According to the calculations made for the dimensions of the wetland, approximately300 Chrysopogonzizanioides seedlings. These will be planted hydroponically by means of modules orrafts designed for this purpose, the modules will occupy approximately $30 \%$ of the water mirror.The wetland will have an approximate production water volume of $7.2 \mathrm{~m} 3$ where the plants are expected to be fully adapted. [23].

At the exit of the wetland we propose to install garden keys to take samples, also have their respective purge tube. In this proposal, the dimensions of the artificial wetland with subsurface flow with Vetiver grass species are proposed. It is highlighted that a subsurface flow wetland needs a substrate and emerging species such as Vetiver Grass.

Considering the above, it can be analyzed that bioremediation should focus on the severity of pollution problems, such as the presence of heavy metals, VOCs, PCBs, etc., which cause public health problems and ecosystem degradation. It 
is established that priority should be given to biological and advanced treatment in order to decrease the concentration of these compounds in the wastewater, soil and air. It must be taken into account that research applied to environmental technology faces problems of lack of investment (due to the fact that market prices do not sufficiently compensate for an adequate care of the environment), slow diffusion, lack of risk capital, aversion to it or bureaucracy. [24].

The tools and methodologies for incorporating sustainability considerations into the design of treatment and disposal operations for both pollutants must be well defined.Vetiver grass is a very probable solution alternative to face the problem of water pollution with oil-based compounds, because of its low cost, easy handling and promotes pollutant removal efficiencies of 44 to $98 \%$. [25]. In the environmental legislation in Colombia and in the world, all waste contaminated with hydrocarbons is considered a hazardous waste; therefore, it cannot be disposed of in soil, water or incinerated in the open air, which has motivated companies in the country and in the world to implement processes for the treatment of contaminated sludge. [26]

\section{CONCLUSIONS}

As an additional or post-treatment process to the system defined for the treatment of production water in the oil sector, a set of alternatives is proposed that constitute a storage lagoon, distribution tank and artificial wetlands, in order to improve the physicochemical conditions of the treated residual water and to reduce the contaminant load of the effluent that is discharged to the soil and/or water sources, with an expected removal effectiveness of more than $90 \%$.

The processes of Bioremediation of hydrocarbon contaminated soils in Colombia are reviewed as a sustainable alternative to the progressive deterioration of the quality of the environment due to the oil spill. The selected alternatives for the treatment of production water in this oil field allow the removal of fats and oils, total suspended solids, dissolved solids, COD, BOD, salts, chlorides, barium, lead, arsenic and selenium, giving an effectiveness range from $60 \%$ to $98 \%$.

These practices should be considered sustainable because of their easy implementation, the low costs generated by the operation and application of the process and the benefit to the environment. Among the positive impacts that these practices have generated, the following can be considered: solution to the problem of generation of sludge contaminated with hydrocarbons, alternatives of final disposal of the same without affecting the soil, water and air resources, the low cost in the operation and technical experience of sustainable development that can continue to be implemented in similar companies where this type of hazardous waste is present.

\section{REFERENCES}

1. Kraus 2010.2 Petróleo: $R$ Prospección 2 perforación, http://www.insht.es/InshtWeb/Contenidos/Documentacion/TextosOnline/nciclopediaOIT/tomo3/75.pdf

2. Frers, C. (2006). El uso de plantas acuáticas para el tratamiento de aguas residuales. p. 1-10.

3. Daza $R$ (2013) Tratamiento de aguas residuales mediante filtros e hidrosistemas naturales conpastovetiver. http://www.vetiver.org/COL_TRATAMIENTO\%20DE\%20AGUAS\%20RESIDUALES\%2OMEDIANTE\%2OFILTROS.pdf.

4. Patino, S y Prada, P. (2016). Alternativas para el diseño del sistema de tratamiento del agua de producción de campo escuela colorado conforme a la normatividad vigente para vertimiento en Colombia. p. 65-80.

5. Andrade, Onelia. (2017). El pasto vetiver: instalación y manejo de viveros. UniversidadAgricola [En línea] http://universidadagricola.com/vetiver-instalacion-manejo-viveros 
6. Pacheco, E; Villegas, M; Pérez, M; Corral, V. (2012). El Petróleo. [En línea] http://platea.pntic.mec.es/ rmartini/petroleo.htm

7. Hirschfeldt, Marcelo. (2015). El manejo del agua producida en la industria petrolera Argentina, Jornal of OilProductionConsulting.

8. SEMARNAT (2003). Norma Oficial NOM-138-SEMARNAT/SS-2003. Límites máximos permisibles de hidrocarburos en suelos y las especificaciones para su caracterización y remediación. 29 de Marzo de 2005.

9. Volke T. y Velasco J. (2002). Tecnologías de remediación para suelos contaminados. Instituto Nacional de Ecología, México, $64 \mathrm{pp}$.

10. Dragun J. y Barkach J.H. (2000). Overview: Fate of Petroleum in Soil systems. En: Assessment and remediation of oil contaminated soils. Arab School on Science and Technology. State of Kuwait. 18-22 March 1995. Amherst, MA: Amherst Scientific Publications.

11. Gurrola-Nevárez B.A. (2008). Tratamiento de un suelo de la industria minera contaminado con hidrocarburos, empleando lodos residuales como fuente alterna de nutrientes: Biorremediación a nivel piloto. Tesis de Maestría. Departamento de Ingenierías Química y Bioquímica. Instituto Tecnológico de Durango. Durango, México, 151 pp.

12. De la Rosa-Pérez D.A., Teutli-León M.M.M. y Ramírez-Islas M.E. (2007). Electrorremediación de suelos contaminados, una revisión técnica para su aplicación en campo. Rev. Int. Contam. Ambie. 23, 129-138.

13. Lee S.H., Lee S., Kim D.Y. y Kim J.G. (2007). Degradation characteristics of waste lubricants under different nutrient conditions. J. Hazard. Mater.143, 65-72.

14. Rivera-Espinoza Y. y Dendooven L. (2004). Dynamics of carbon, nitrogen and hydrocarbons in diesel-contaminated soil amended with biosolids and maize. Chemosphere 54, 379-386.

15. Osorio-Rodríguez A.L. (2010). Biorremediación a nivel piloto de un suelo contaminado con hidrocarburos del petróleo empleando lodos compostados como fuente alterna de nutrientes. Tesis de Licenciatura. Departamento de Ingenierías Química y Bioquímica. Instituto Tecnológico de Durango.

16. Vianna, Javier. (2009). Guía para la disposición y el tratamiento de agua producida, Asociación regional de empresas de petróleo y gas natural en Latinoamérica y el Caribe (ARPEL)

17. Hengchaovanich, D. \&Nilaweera, N. (2012). Anassessment of sthengtth properties of vetiver grass todos.In relation to slope stabilization.Proceedings of the first international conference of vetiver. Office of the Royal Development progectes boar, Bangkok

18. Tratamiento de aguasresiduales con Pasto Vetiver. (2015). [En línea] https://es.slideshare.net/julioestrada/tratamiento-deaguas-residuales-con- vetiver

19. Delgadillo, O.; Camacho, A.; Pérez, L.; Andrade, M. (2010). Depuración de aguas residuales por medio de humedales artificiales. Bolivia. Serie Técnica.

20. Marín, Loaiza (2016) rehabilitación de suelos degradados con ChrysopogonZizanioides

21. SCAVO, Mónica. et al. (2005) Estudio de un sistema de tratamiento de aguas residuales complementario, con Pasto vetiver (Vetiveriazizanioides l.), provenientes de una planta de producción de gaseosas, en villa de cura, Estado Aragua”. p.6-9.

22. Sanabria, O. (2012). Humedales Artificiales de Alta Tasa - HAATReactores de flujo horizontal subsuperficial para el tratamiento de aguas residuales domésticas e industriales. 
23. Romero. Rojas J.A. (2011) Tratamiento de Aguas Residuales. Editorial Escuela Colombiana de Ingenieros, Tercera Ediciòn.

24. Di Paola, M. Vicien C. Biorremediaciòn: vinculaciones entre investigaciones, desarrollo y legislación. Argentina: CEURTCONICET 2010.

25. Guemini-Schenberg AC. Biotechnology and sustainable development, study advanced 2010; 24 (April 2008).

26. World Health Organization Ambient air pollution: A global assessment of exposure and burden of disease. Geneve: WHO; 2016. 
